\title{
ISOLATION AND CHARACTERIZATION OF METHICILLIN RESISTANT STAPHYLOCOCCUS AUREUS (MRSA) FROM TABLE EGGS
}

\author{
MARWA M.N. EL-GENDI and MANAL M. AMIN \\ Animal Health Research Institute (Assiut Provincial Lab.) Food Hygiene Department
}

Received: 11 February 2019; Accepted: 6 March 2019

\begin{abstract}
Eggs continue to be significant in terms of the world economy and human nutrition and routine non-therapeutic antimicrobial use and overcrowding in animal farming may facilitate the propagation of Methicillin-Resistant Staphylococcus aureus (MRSA). The aim of this study was to estimate the prevalence of MR Staphylococcus aureus (MRSA) in table eggs production. Three hundred and fifty eggs represent 35 samples from balady egg and 35 sample from poultry farm egg (each sample $5 \mathrm{egg}$ ) were tested for isolation of Staphylococcus aureus. These findings are important for local risk assessments concerning possible human foodborne infections via cross-contamination of eggs. S. aureus was isolated from balady and poultry farm egg shell in percentage of 57.1 and $80 \%$, also $S$. aureus could be isolated from the content of balady and poultry farm egg in percentages of 74.4 and $85.8 \%$, respectively. In addition, S. aureus was identified by the coagulase test and our findings showed that 37.1 and $51.4 \%$ of examined samples of balady and poultry farm, respectively were coagulase positive $S$. aureus. Notably, $34.3 \%$ and $48.6 \%$ of coagulase positive $S$. aureus isolates were isolated from balady and poultry farm egg contents, respectively. The results revealed that the incidence of coagulase negative staphylococci on examined balady egg shell and contents were 20 and 40\%, respectively. Coagulase negative staphylococci was isolated in a percentage of $10(28.6 \%)$ and $13(37.1 \%)$ from examined poultry farms egg shells and contents. Identification mecA gene carriage, hence MRSA, using polymerase chain reaction (PCR) revealed that 3 from 10 samples were positive for mecA by using (PCR) in percentage of (30\%). Risk of egg borne disease strongly increases because of unhygienic conditions of egg production and improper practices of egg handling, including also storage times and temperatures. If all the necessary precautions are not taken during the poultry production, marketing and processing chains in that case poultry meat and eggs can be contaminated by infectious agents that are harmful to humans.
\end{abstract}

Key words: MRSA - Table egg

\section{INTRODUCTION}

Table eggs are nutritionally important food consumed globally. Despite being protected inside the hard shell and a semipermeable membrane, the egg contents may be contaminated with microbes and thus become a possible carrier of infectious agents to humans. Also, table eggs are consumed worldwide and are considered the most nutritious inexpensive source of protein that can be part of a healthy diet. However poultry may carry bacteria that can cause illness, infected birds do not usually appear sick and even unbroken clean fresh shell eggs may contain harmful bacteria. (Barbara and Ron, 2010). Special attention has been paid for raw or undercooked eggs because the hens act as natural reservoirs of a variety of pathogens. The contamination occurs through the shell; but

Corresponding author: Dr. MARWA M.N. EL-GENDI E-mail address: ahmednofel125@yahoo.com

Present address: Animal Health Research Institute (Assiut Provincial Lab.) Food Hygiene Department humidity, temperature and storage time are critical for migration of bacteria from the surface of the shell to the inner structures of the egg (Evêncio et al., 2012). Egg is an excellent source of choline and selenium and a good source of vitamin B12, riboflavin and phosphorus. The yolk contains different vitamins such as $\mathrm{A}, \mathrm{D}, \mathrm{E}$ and $\mathrm{K}$ as well as folic acid and zinc (ENC, 2004). The extent of egg spoilage due to effect of microorganisms is very high which result in big economic losses (Saif et al., 2009; Howard et al., 2011). At the beginning, the microbial load is very low but it increases when the shell acquires at oviposition, a few are from the vent and others from the nesting materials and feces. Besides these egg can be contaminated from different stages like during collection, handling, storage and transportation.

A number of medically significant bacterial species have already been reported from table eggs. More important is the presence of antimicrobial-resistant bacterial strains in this food source. There is now considerable evidence that transfer of antimicrobial 
resistance from food-producing animals to humans directly via the food chain is a likely route of spread, transmission by direct handling or close contact between infected animals and humans, transmission via contaminated animal products, particularly but not exclusively food products. The World Organization for Animal Health (OIE) has developed a list of antibiotics categorized by the need for their use in animal treatment; Thus these antibiotics may all affect bacteria in both animal and human treatment settings (Wooldridge, 2012).

Staphylococcus aureus strains are now regarded as zoonotic agents. In pastoral settings where humananimal interaction is intimate, multi-drug resistant microorganisms have become an emerging zoonotic issue of public health concern. The study of $S$. aureus prevalence, antimicrobial resistance and clonal lineages in humans, animals and food in African settings has great relevance, taking into consideration the high diversity of ethnicities, cultures and food habits that determine the lifestyle of the people (Asiimwe et al., 2017).

Staphylococcus is considered to be a normal flora of chickens, isolated from the skin and feathers as well as in the respiratory and intestinal tracts (Casey et al., 2007). However, some of the common forms of Staphylococci are associated with poultry infections. Increasing attention has been given to the role of poultry and poultry products, including eggs, as a potential source of infections in humans induced by antibiotic-resistant Staphylococcus strains (Abulreesh and Organji 2011). S. aureus is a medically significant bacterial species responsible for diverse types of infections ranging from superficial skin and soft-tissue infections to fasciitis, otitis media, necrotizing pneumonia, and urinary infections (Tamarapu et al., 2001; Harris et al., 2002). In addition, S. aureus is one of the major causes of food poisoning due to their ability to produce heat-stable enterotoxins that may remain protected in the food environment and cause foodborne illness (Bergdoll et al., 1967; Argudı'n et al., 2010). There are over 20 types of staphylococcal enterotoxins (SE), two of them (SEA and SEB), that are best characterized and considered super antigens as they may bind MHC II molecules on the surface of antigen-presenting cells and may stimulate massive $\mathrm{T}$ cell proliferation and ultimately leading to toxic shock (McCormick et al., 2001; Le Loir et al., 2003; Rahimi et al., 2013; Kadariya et al., 2014).

Methicillin-Resistant S. aureus (MRSA) shows resistance against almost all b-lactam antibiotics, including penicillin and cephalosporins. Resistance against b-lactam antibiotics is due to bacterial ability to produce an altered form of penicillin-binding proteins (PBP), that is, $\mathrm{PBP} 2 \mathrm{a}$ that has lowered affinity for b-lactam drugs. The mecA gene located on the chromosomal DNA of MRSA strains encodes PBP2a. This mecA gene is a part of staphylococcal cassette chromosome mec (SCCmec), a mobile genetic element that may be horizontally transferred among strains of $S$. aureus, causing dissemination of antimicrobial resistance genes among the isolates. Strains devoid of SCCmec are sensitive to methicillin and are termed as methicillin-sensitive $S$. aureus (Stapleton and Taylor, 2002).

There is a very limited data available on the presence of $S$. aureus in table eggs (Abdullah, 2010; Pyzik et al., 2014). These studies primarily focused on bacterial detection and antimicrobial susceptibility testing. The presence of MRSA in table eggs will not only indicate a risk of foodborne illness, but also a source of dissemination of antimicrobial-resistant strains to humans and the environment (De Reu et al., 2005; Woodridge, 2012). It is very important for public health to ensure the quality and safety of eggs. However, foodborne illness due to the ingestion of eggs contaminated with pathogens occasionally occurs all over the world. Therefore, it is necessary to enhance the surveillance and risk assessment of egg safety.

Methicillin-Resistant S. aureus (MRSA) was identified in 1962 and, together with certain species of Enterococcus, are currently considered as global pandemic threats (CDC 2013; Rossolini et al., 2014). MRSA is a major cause of severe healthcareassociated (HA) infections. Although during the last decade the incidence of HA invasive infections has dropped, the incidence of community- associated MRSA (CA-MRSA) infections has risen among the general population. Moreover, CA-MRSA, livestock-associated MRSA (LA-MRSA) and HAMRSA (HA-MRSA) can be found in foods intended for human consumption (Sergelidis and Angelidis 2017). The contamination sources for foods, especially animal-origin foods, may be livestock as well as humans involved in animal husbandry and food-processing. Since the early 1990s, MRSA strains have emerged, which are involved in community-associated infections (nonhospital related) in humans in many countries (communityassociated, methicillin-resistant $S$. aureus, CAMRSA) (Deurenberg et al., 2007). Moreover, in recent years, the isolation of MRSA from livestock (livestock-associated, methicillin-resistant S. aureus, LA-MRSA) and companion animals has also been reported (Wendlandt et al. 2013; Vincze et al., 2014). HA-MRSA and CA-MRSA are believed to predominantly affect humans and, in general, are not involved in live- stock infections. However, humans may harbour LA-MRSA, especially in cases where there is occupational contact with affected livestock (Cuny et al., 2015). Furthermore, overlaps between these different MRSA reservoirs have been reported, including nosocomial infections by CA-MRSA 
(Skov and Jensen 2009) and isolation of LA-MRSA from the hospital environment (Van Rijen et al., 2008). The incidence of invasive HA-MRSA infection seems to be declining (Rossolini et al., 2014), while a rapid rise of CA-MRSA infections has been observed among the general population (CDC 2013). The traditional epidemiological classification of MRSA into HA-MRSA, CA-MRSA and LA MRSA may no longer be valid because there are considerable overlaps of identical clones between these groups (Bal et al., 2016).

The objective of the present study was aimed to isolate and identify the MRSA from egg shell and egg contents.

\section{MATERIALS AND METHODS}

Sample collection: A total of 350 random eggs, representing 70 samples, (35 from balady egg, and 35 from poultry farms) were collected from, poultry farms, groceries, framers, supermarkets and rural area located in Assiut Governorate, Egypt. Each egg sample (composed of 5 eggs) was placed in a sterile plastic bag and dispatched to the laboratory with a minimum of delay where they were prepared and examined.

\section{Preparation of samples:}

Egg shells: Egg shells were tested by a surface rinse method as described by Moats (1980).

Egg contents: The egg sample was prepared for evacuation of its content according to Speck (1976).

Isolation and Identification of $S$. aureus from table egg according to Bennett and Lancette (2001): All the samples were prepared and enriched on Staphlococci broth for $20 \mathrm{~h}$ at $35{ }^{\circ} \mathrm{C}$ and then inoculated onto Baird Parker Medium (Oxide, Basingstoke, England), and incubated aerobically at $37{ }^{\circ} \mathrm{C}$ for $24 \mathrm{~h}$. The isolates were identified using established microbiological methods which included colony morphology, Gram staining and biochemical testing [catalase, coagulase and sugar fermentation (glucose, sucrose, lactose and mannotol)].

Identification and characterization of coagulase positive and negative Staphylococcus Species: the isolates were identified according to (ISO, 2003b).

Coagulase test according to (ISO, 2003b):

Five colonies typical and atypical were selected from each plate. The selected colonies inoculated into $5 \mathrm{ml}$ Brain Heart Infusion broth. The tubes were incubated at $37^{\circ} \mathrm{C}$ for 24 hours. From which $0.1 \mathrm{ml}$ was transferred to tubes containing $0.3 \mathrm{ml}$ of sterile citrated rabbit plasma. Inoculated tubes were incubated at $37^{\circ} \mathrm{C}$ and examined for clot formation after 4 hours.

Isolation of antibiotic resistant $S$. aureus: (CLSI /NCCLS (2001)

Antimicrobial susceptibility pattern of $S$. aureus isolates were determined by using disk diffusion assay following the guidelines of Clinical and Laboratory Standard Institute. The pre-incubated 24 hours cultures of $S$. aureus were diluted in sterile buffer peptone water and matched with the 0.5 MacFarlane turbidity standards to get $1 \times 10^{8} \mathrm{cfu} / \mathrm{ml}$ as total count. Bacterial suspensions were spread on Muller-Hinton agar (Merck, Germany). The antibiotic discs (Methicillin $1 \mu \mathrm{m}$ ) were placed over the lawn and incubated at $37{ }^{\circ} \mathrm{C}$ for $18-24$ hours. The clear zone around each antibiotic disc was measured in millimeter according to zone size interpretation chart modified from NCCLS (2001).

\begin{tabular}{ccccc}
\multirow{2}{*}{$\begin{array}{c}\text { Disc content in } \\
\mu \mathrm{m}\end{array}$} & $\begin{array}{c}\text { Antimicrobial } \\
\text { agent }\end{array}$ & Resistant & Intermediate & Susceptible \\
\cline { 3 - 4 } & & & $11-12$ & 13 \\
\hline & Methicillin & 10 & & \\
\hline
\end{tabular}

\section{Detection of $m e c A$ gene by Polymerase chain reaction $(P C R)$ :}

DNA extraction. DNA extraction from samples was performed using the QIAamp DNA Mini kit (Qiagen, Germany, GmbH) with modifications from the manufacturer's recommendations. Briefly, 200 $\mu 1$ of the sample suspension was incubated with 10 $\mu \mathrm{l}$ of proteinase $\mathrm{K}$ and $200 \mu \mathrm{l}$ of lysis buffer at $56^{\circ} \mathrm{C}$ for $10 \mathrm{~min}$. After incubation, $200 \mu \mathrm{l}$ of $100 \%$ ethanol was added to the lysate. The sample was then washed and centrifuged following the manufacturer's recommendations. Nucleic acid was eluted with $100 \mu$ l of elution buffer provided in the kit.

Oligonucleotide Primer: Primers used were supplied from Metabion (Germany), the following table showing primers sequences, target genes, amplicon sizes and cycling conditions: 


\begin{tabular}{|c|c|c|c|c|c|c|c|c|}
\hline \multirow{2}{*}{$\begin{array}{l}\text { Target } \\
\text { gene }\end{array}$} & \multirow{2}{*}{$\begin{array}{c}\text { Primers } \\
\text { sequences }\end{array}$} & \multirow{2}{*}{$\begin{array}{c}\text { Amplified } \\
\text { segment } \\
\text { (bp) }\end{array}$} & \multirow{2}{*}{$\begin{array}{c}\text { Primary } \\
\text { Denaturation }\end{array}$} & \multicolumn{3}{|c|}{ Amplification (35 cycles) } & \multirow{2}{*}{$\begin{array}{c}\text { Final } \\
\text { extension }\end{array}$} & \multirow[b]{2}{*}{ Reference } \\
\hline & & & & $\begin{array}{c}\text { Secondar } \\
\text { denaturation }\end{array}$ & Annealing & Extension & & \\
\hline mecA & $\begin{array}{c}\text { GTA GAA } \\
\text { ATG ACT } \\
\text { GAA CGT } \\
\text { CCG ATA A } \\
\text { CCA ATT CCA } \\
\text { CAT TGT TTC } \\
\text { GGT CTA A } \\
\end{array}$ & 310 & $\begin{array}{l}94^{\circ} \mathrm{C} \\
5 \mathrm{~min} .\end{array}$ & $\begin{array}{c}94^{\circ} \mathrm{C} \\
30 \mathrm{sec} .\end{array}$ & $\begin{array}{c}50^{\circ} \mathrm{C} \\
30 \mathrm{sec} .\end{array}$ & $\begin{array}{c}72^{\circ} \mathrm{C} \\
30 \mathrm{sec} .\end{array}$ & $\begin{array}{l}72^{\circ} \mathrm{C} \\
7 \mathrm{~min}\end{array}$ & $\begin{array}{c}\text { McClure } \\
\text { et al., } \\
2006\end{array}$ \\
\hline
\end{tabular}

PCR amplification. Primers were utilized in a 25$\mu \mathrm{l}$ reaction containing $12.5 \mu \mathrm{l}$ of EmeraldAmp Max PCR Master Mix (Takara, Japan), $1 \mu$ l of each primer of 20 pmol concentration, $4.5 \mu \mathrm{l}$ of water, and $6 \mu \mathrm{l}$ of DNA template. The reaction was performed in an Applied biosystem 2720 thermal cycler.

Analysis of the PCR Products.
The products of PCR were separated by electrophoresis on $1.5 \%$ agarose gel (Applichem, Germany, GmbH) in $1 \mathrm{x}$ TBE buffer at room temperature using gradients of $5 \mathrm{~V} / \mathrm{cm}$. For gel analysis, $20 \mu \mathrm{l}$ of the uniplex PCR products Gelpilot 100 bp DNA ladder (Qiagen, Germany, $\mathrm{GmbH}$ ) was used to determine the fragment sizes. The gel was photographed by a gel documentation system (Alpha Innotech, Biometra) and the data was analyzed through computer software.

\section{RESULTS}

Table 1: Incidence of isolated staphylococcal species in the examined table eggs shell samples.

\begin{tabular}{lccc}
\hline Type of samples & $\begin{array}{c}\text { No. of samples } \\
\text { analyzed }\end{array}$ & $\begin{array}{c}\text { No. of } \\
\text { Positive samples }\end{array}$ & $\%$ \\
\hline Balady egg shells & 35 & 20 & 57.1 \\
\hline Poultry farm egg shells & 35 & 28 & 80 \\
\hline
\end{tabular}

Table 2: Incidence of isolated staphylococcal species in the examined hen's eggs content samples.

\begin{tabular}{lccc}
\hline \multicolumn{1}{c}{ Type of samples } & $\begin{array}{c}\text { No. of samples } \\
\text { analyzed }\end{array}$ & Positive samples & $\%$ \\
\hline Balady egg contents & 35 & 26 & 78.4 \\
\hline Poultry farm egg conents & 35 & 30 & 85.8 \\
\hline
\end{tabular}

Table 3: Occurrence of $S$. aureus and coagulase negative staphylococci from examined samples.

\begin{tabular}{lccccccc}
\hline \multirow{2}{*}{ Examined samples } & \multirow{2}{*}{$\begin{array}{c}\text { No. of } \\
\text { examined } \\
\text { samples }\end{array}$} & \multicolumn{2}{c}{$\begin{array}{c}\text { Coagulase positive } \\
\text { S. aureus }\end{array}$} & \multicolumn{2}{c}{$\begin{array}{c}\text { Coagulase negative } \\
\text { staphylococci }\end{array}$} & \multicolumn{2}{c}{ Total } \\
\cline { 3 - 8 } Balady egg shells & 35 & 13 & 37.1 & 7 & 20 & 20 & 57.1 \\
\hline Poultry farm egg shells & 35 & 18 & 51.4 & 10 & 28.6 & 28 & 80 \\
\hline Balady egg contents & 35 & 12 & 34.3 & 14 & 40 & 26 & 74.3 \\
\hline $\begin{array}{l}\text { Poultry farm egg } \\
\text { contents }\end{array}$ & 35 & 17 & 48.6 & 13 & 37.1 & 30 & 85.8 \\
\hline Total & 140 & 60 & 42.9 & 44 & 31.4 & 104 & 74.3 \\
\hline
\end{tabular}


Table 4: Antimicrobial susceptible profile of $S$. aureus isolated from examined samples.

\begin{tabular}{lcccccc}
\hline \multirow{2}{*}{ S. aureus strains isolated from } & \multicolumn{2}{c}{ Resistant strains } & \multicolumn{2}{c}{ Intermediate strains } & \multicolumn{2}{c}{ Sensitive strains } \\
\cline { 2 - 7 } & No. & Freq.\% & No. & Freq.\% & No. & Freq.\% \\
\hline Balady egg shells & 0 & 0 & 3 & $23.1 \%$ & 10 & $77 \%$ \\
Poultry farm egg shells & 3 & $16.7 \%$ & 5 & $27.8 \%$ & 10 & $55.6 \%$ \\
Balady egg contents & 0 & 0 & 3 & $25 \%$ & 9 & $75 \%$ \\
Poultry farm egg contents & 7 & $41.2 \%$ & 2 & $11.8 \%$ & 8 & $47 \%$ \\
\hline
\end{tabular}

Table 5: Freqency $\%$ of $m e c A$ gene in the examined of table egg samples by using PCR technique.

\begin{tabular}{cccc}
\hline & \multirow{2}{*}{ No. of examined samples } & \multicolumn{2}{c}{ mecA } \\
\cline { 3 - 4 } Examined samples & & No. & $\%$ \\
\hline Balady egg shells & 3 & 0 & $0 \%$ \\
Poultry farm egg shells & 0 & 1 & $33.3 \%$ \\
Balady egg contents & 7 & 0 & $0 \%$ \\
Poultry farm egg contents & 2 & 2 & $28.6 \%$ \\
\hline
\end{tabular}

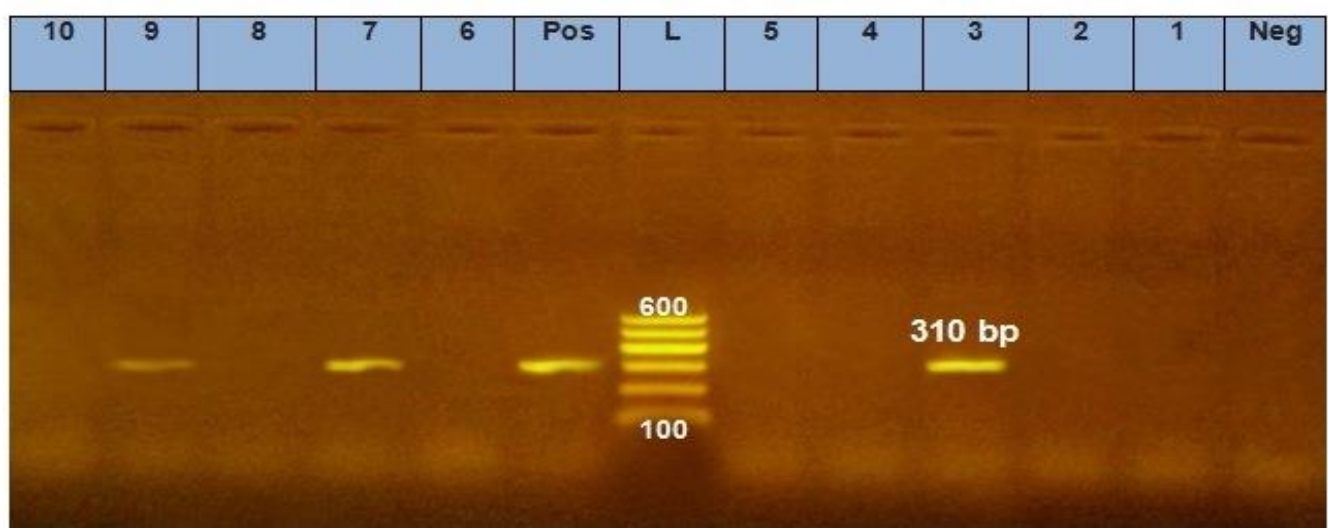

Fig. 1: PCR result of mecA gene among Coagulase positive S. aureus isolates. Lane L: ladder, lane pos: control positive, lane neg: control negative lane 3,7,9 (+ve mecA). lane 1,2,4,5,6,8,10 (-ve mecA).

\section{DISCUSSION}

Humans have been fighting the battle against antimicrobial resistance among bacteria; the disease caused by resistant $S$. aureus strains among those on prolonged antibiotic therapy may be difficult to be controlled. Of further concern is dissemination of these resistant bacteria to food, the environment, and animals. Antimicrobial resistance profiles of the S.aureus strains isolated from egg samples were comparable to those reports published in other parts of Egypt in humans, which is an alarming situation (Taj et al., 2010). Injudicious and uncontrolled use of antimicrobials while treating farm animals and antimicrobial use in poultry feed may be possible explanations for MRSA in eggs in this study, since previous experimental studies on table eggs have already proved bacterial penetration of egg shells
(Berrang et al., 1999). Therefore, resistant bacterial strains may easily enter the egg and contaminate them. An additional explanation for the results of this study may be transfer of human antimicrobial resistant strains to poultry.

The requirements for the table eggs include high nutritional value and digestibility as well as safety of use in the everyday diet of millions of people worldwide. Taking these criteria into account, the presence of pathogenic bacteria in food, including table chicken eggs, may pose a serious health problem (food poisoning and foodborne infections), considering the fact that many foods containing eggs or egg products undergo no thermal treatment, or thermal treatment insufficient to neutralize these pathogens (Baumann-Popczyk and SadkowskaTodys 2012, Pyzik and Marek 2012). At the time of 
laying, the eggs are sterile due to natural chemicals and physical defenses against microbial infection, but on exposure to environmental conditions as temperature and length of storage eggs were contaminated by different types of microorganisms which cause spoilage and public health problems (Abd Elhady and Emara, 1997). The egg shell acts as a natural packing material for the egg contents, preventing the penetration of harmful bacteria.

The present study revealed a high rate of total Staphylococcus contamination of table chicken eggs, which were $20(57.1 \%)$ and $28(80 \%)$ isolates from shell of balady and poultry farm egg and 26 (74.4) and 30 (85.8) strains from contents of balady and poultry farm eggs respectively (Table $1 \& 2$ ). Samah et al. (2015) showed the presence of Coagulase Positive Staphylococci both on the shell and in the contents, 80 isolates were detected with an overall prevalence rate of $40 \%$. Isolation rates were 29(14.5\%), $15(7.5 \%)$, and $36(18 \%)$ from the shell, contents, and both shell and contents, respectively. Higher prevalence rates were recorded by (Stepień et al., 2009) when they reported the isolation of Coagulase Positive Staphylococci from eggs with a rate of $45.7 \%$, of which $2.5 \%, 38.7 \%$, and $58.8 \%$ were detected from white, yolk, and on the shell, respectively. One of the typical features that distinguish the more pathogenic Staphylococcus strains from the less pathogenic is the ability to produce free coagulase and bound coagulase (clumping factor). This feature is also considered as one of the virulence factors (Bannerman 2003, MacFaddin 2000). During storage on farms or in the packing centers, as well as during transport, poor handling practices can lead to the disruption of the egg's physical barriers. The presence of cracks increases the risk of bacterial contamination of the broken egg and of other eggs if the cracked ones leak, affecting the quality of the shell and that of the egg contents (EFSA, 2014).

A total 104 staphylococcal isolates were isolated from 140 samples of balady and poultry farm egg shell and contents in present study (Table 3). $13(37.1 \%)$ and $18(51.4 \%)$ isolates were identified as coagulase positive $S$. aureus from the shell of balady and poultry farm respectively. While, 12 (34.3\%) and $17(48.6 \%)$ isolates were identified as coagulase positive $S$. aureus from contents of balady and poultry farm egg. In addition, the obtained results showed that $7(20 \%), 10(28.6 \%), 14(40 \%)$ and $13(37.1 \%)$ from isolate of shell and contents of balady and poultry farm, respectively, were contaminated with coagulase negative staphylococci. It is clear that percentage of CNS was low 44 (31.4\%) compared to CPS $60(42.9 \%)$ and this is lower than results obtained by Goja et al. (2013); Yurdakul et al. (2013); Piyali and Pranab (2016), the latter found that the percentage of CNS $(60 \%)$ was higher than that of CPS $(40 \%)$. Also, higher incidence $(52.00 \%)$ of the unacceptable samples was associated with coagulase positive staphylococci could be detected by Eman and Saad (2015) and Shimaa El-Nagar et al., 2017 revealed that staphylococci were detected in $26.7 \%$ of table eggs; $16.7 \%$ for $S$. aureus and $10 \%$ for CNS. In addition, Syed et al. (2018) could detect that $21.3 \%$ (64/300) of samples were contaminated with Staphylococcus which were isolated from the three parts of table egg and they found that the maximum number of staphylococci were isolated from egg yolk that represented $37.5 \%$ (24/64), followed by $34.4 \%$ $(22 / 64)$ from egg white, and $28.1 \%(18 / 64)$ from the inner membrane of egg shells.

The number of CNS isolated in this study could be justified by the fact that CNS are found abundantly in the normal teat skin flora and mucosa of humans and animals while some are free living in the environment (Addis et al., 2011). Staphylococci can be divided into two groups according to the production of Coagulase enzyme, which is capable of coagulating blood plasma. The synthesis of this enzyme is restricted to some species in the genus, among which $S$. aureus. The other Staphylococci that do not synthesize coagulase are referred to as Coagulase Negative Staphylococci (Koneman, 1997).

The present study was to establish the presence of methicillin-susceptible $S$. aureus MRSA in table egg so detailed analysis of the isolated $S$. aureus strains positive for mecA gene among coagulase positive $S$. aureus isolates demonstrated that only three out of the 10 isolated strains in percentage of $30 \%$ containing mecA (Table 5). Syed et al. (2018) showed that prevalence of MRSA in table eggs was $11 \%$ (33/300). S. aureus strains, especially those resistant to methicillin (MRSA) have been regarded as zoonotic agents and there is growing genuine concern about the likely transmission of MRSA between animals and humans from close interaction or from handling and/or consuming MRSA infected animal products (Garcia-Alvarez et al., 2011). In settings where humans depend on animals and their products for food and livelihood, such as in pastoral Africa, contact is intimate and multi-drug resistant microorganisms have become an emerging veterinary and zoonotic issue of public health concern (Kasozi et al., 2014 and Kamau et al., 2013). Additionally, S. aureus is known to be the third most reported cause of food-borne diseases in the world (Normanno et al., 2007).

Staphylococci are most common bacteria contaminating eggshells. Contamination is more likely linked with cracked egg, dirty shells and storage in contaminated surroundings. It can be contaminated during formation and laying process (Abdullah, 2010). The eggshell contamination 
increasing the chances of egg contents contamination by penetration (Messens et al., 2006). Bacterial contamination can happen at three main parts of egg (egg yolk, albumen and shell membrane / egg shell) (Bahrouz and Al-Jaff 2005). S. aureus is one of most common foodborne pathogens (Akbar and Anal, 2013a; Ghasemian, 2011; Akbar and anal, 2011). Eggs and egg products were responsible for $11 \%$ of all cases of staphylococcal food poisoning (Haeghebaert et al., 2002).

Detection of the mecA gene, therefore, would be a good way of standardizing identification of MRSA across laboratories. The results are similar to those in another study comparing methods for the detection of MRSA on isolates from foods of animal origin in Italy by Corrente et al. (2007). and they concluded that analysis for MRSA in isolates from food of animal origin is better done with the mecA gene-specific PCR rather than conventional phenotypic assays (Corrente et al., 2007). The mecA gene was detected as $28.6 \%$ and $33.3 \%$ among $S$. aureus isolates from poultry farm egg contents and shells, respectively. Electrophoresis analysis of PCR amplification products using genus specific primer (mecA gene) showed that (Fig. 1). (Lane L: ladder, lane pos: control positive, lane neg: control negative lane 3,7,9 (+ve mecA). lane 1,2,4,5,6,8,10 (-ve mecA). Shimaa El-Nagar et al. (2017) could detect the presence of gene mecA in higher percentages $(66.7 \%)$ of examined samples.

The absence of standard structures and drainage system in the market and the relatively high humidity could have contributed to the high microbial growth. It was also found out that most retailers do not store eggs in refrigerators, thus the eggs are exposed to weather conditions, resulting in their contamination. The isolated microbes could cause severe health problems like, diarrhea, nausea and abdominal pain, since they are pathogenic (Adday et al., 2009). S. aureus strains from processed poultry are thought to be human strains endemic to the processing plant or from the hands of workers in the plant. The literature varies as to the 61 origin of processing plant strains with biotyping indicating the passage of human staphylococcal strains to poultry in processing plants; plasmid profiling indicates that endemic strains in the processing plant are introduced by incoming birds.

Eggs have natural defense system against the contaminating microbes, such ascuticle, calcium hard shell and shell membrane (Jerzy and Dagmara, 2009). The albumen contains several egg white proteins that have antimicrobial properties, especially the lysozyme. Ovomucoid is another proteinase that inhibits the ability of bacterial to use the protein in albumen. Furthermore, the $\mathrm{pH}$ in albumen which is about 9-10 and the viscosities of the egg white are not suitable for microbial growth (Froning, 1998). Egg can be contaminated at both egg shell and egg contents by a variety of microbes with a wide range of pathogens such as Campylobacter jejuni, Listeria monocytogenes, Escherichia coli, Yersinia enterocolitica and especially salmonella (Ricke et al., 2001; Board and Tranter, 1995).

Consumers are at a high risk of infection because most of the organisms isolated are pathogenic to humans. Ensuring good hygienic standards at the various markets and farm houses in the metropolis is a shared responsibility between stakeholders, government, consumers and retailers. Retailers in particular should be impressed upon to endeavour to store and retail their eggs under refrigerated or good sanitary conditions to reduce microbial contaminations.

Backyards flocks are reared under limited or no veterinary supervision. In such production systems, antimicrobials are freely used as feed or water additives (Otalu et al., 2011). These practices can facilitate the emergence and spread of antibiotic resistant pathogens among birds with possible transmission to humans. Backyard chickens are extensively reared in close proximity to human dwellings and therefore play an important role in environmental contamination, in addition to serving as significant vehicles for the transfer of pathogens to humans by way of handling of live birds or consumption of contaminated meat and other poultry products. (Suleiman et al., 2013). Eggs produced from backyard house hold chickens in Egyptian villages are commonly used for own consumption or to be sold in local markets, (most commonly used unwashed).

The eggs from supermarkets were not stored at refrigerated temperatures and the level of contamination in eggs collected from these sites was considerable. Thus, we suggest that supermarkets should store eggs at refrigerated temperatures to control the contamination of table eggs. The results in this study also indicate that contamination may occur at the farm level rather than during handling. The data underscore the need for optimum hygienic conditions at the farm level to decrease the bacterial load in commercial chicken eggs. Despite the difference in the type of bacterial growth and different number of isolates in each group, this difference was statistically non-significant. This indicates that all types of table eggs in the current study are not handled in healthy conditions. 


\section{CONCLUSION}

The presence of MRSA in eggs is a matter of food safety and alternatively a source of dissemination of resistant strains to humans through the food chain. Antimicrobial resistance of these strains against commonly used antibiotics to cure human diseases is of public health concern. Proper sanitation in the poultry farms, improved storage conditions, as well as judicious and controlled use of antibiotics in the poultry industry are all important to control bacterial carriage and health risks by contaminated table eggs. We conclude from this study that eggs are exposed to contamination due to bad storage conditions in storehouse, wrong show in market, dirty table, high temperature, dust, hand touching, and all other surrounding pollution state, also consumers should keep egg in refrigerator and cooked egg well to kill bacteria. Finally the trade people must be transport egg from good source and good hen farms because the type of rearing (cage or floor) greatly effect on quality of egg and also from countries empty from dangerous zoonotic diseases. So, this study holds a great importance to understand the present risks of table egg borne diseases on human health and will help to take necessary measures to reduce the risk by creating public awareness, improving knowledge in rural women, good hygiene practices, thorough cooking, provision of vaccines and essential medicines and development of linkages with the different agencies.

\section{REFERENCES}

Abd Elhady, H.M. and Emara, M.M.T. (1997): Hazard analysis and critical point evaluation of eggs and basterma meal. Alex. J. Vet. Science, 13(1): 63-73.

Abdullah, I.N. (2010): Isolation and identification of some bacterial isolates from table egg. AlAnbar J. Vet. Sci.;(3): 59-67.

Abulreesh, H.H. and Organji, S.R. (2011): The Prevalence of Multidrug-resistant Staphylococci in Food and the Environment of Makkah, Saudi Arabia. Res. J. Microbiol. 6: 510-523.

Adday, S.; Ansah, T.G.S.K.; Dzoagbe, G.A.; Teye, S. and Danquah, J.K. (2009): Microbial Quality of Table Eggs Sold on Selected Markets in the Tamale Municipality in the Northern Region of Ghana. Livestock Res. For Rural Dev., 21 (8).

Addis, M.; Pal, M. and Kyule, M.N. (2011): Isolation and identification of Staphylococccus species from raw bovine milk in DebreZeit, Ethiopia, Veterinary Research 4(2), 45-49.

Akbar, A. and Anal, A.K. (2013a): Prevalence and antibiogram study of Salmonella and Staphylococcus aureus in poultry meat.
Asian Pacific Journal of Tropical Biomedicine. 3(2): 163-168.

Akbar, A. and Anal, A.K. (2011): Food safety concerns and food-borne pathogens, Salmonella, Escherichia coli and Campylobacter. FUUAST Journal of Biology. 1(1): 5-17.

Argudi'n, M.A.; Mendoza, M.C. and Rodicio, M.R. (2010): Food poisoning and Staphylococcus aureus enterotoxins. Toxins;(2): 1751-1773.

Asiimwe, B.; Rossella, B.; Alberto, T. and Daniela, M.C. (2017): Prevalence and molecular characteristics of Staphylococcus aureus, including methicillin resistant strains, isolated from bulk can milk and raw milk products in pastoral communities of SouthWest Uganda. BMC Infectious Diseases, 17: 422.

Bahrouz, M.A. and Al-Jaff (2005): The risk of bacterial contamination in hen eggs of Sulaimani poultries. Journal of Zankoy Sulaimani. 8A (1): 63-71.

Bal, A.M.; Coombs, G.W.; Holden, M.T.G.; Lindsay, J.A.; Nimmo, G.R.; Tattevin, P. and Skov, R.L. (2016): Genomic insights into the emergence and spread of international clones of healthcare-, community- and livestock-associated meticillin-resistant Staphylococcus aureus: blurring of the traditional definitions. J. Glob. Antimicrob. Resist., 6: 95-101.

Bannerman, T.L. (2003): Staphylococcus, Micrococcus, and other catalase-positive cocci that grow aerobically. In: Manual of clinical microbiology, ASM Press, Washington D.C, pp. 264-282.

Barbara Ingham and Ron Kean (2010): Egg Safety and the Backyard Flock University of Wisconsin-Madison and University of Wisconsin-Extension Adapted with permission from Home-Produced Chicken Eggs (Colorado State University Extension bulletin no. 9.377 (updated 5/12/2010)) by M. Bunning and J. Avens. For information, contact Dr. Barbara Ingham bhingham@wisc.edu or Ron Kean at rpkean@wisc.edu 1/2011.

Baumann-Popczyk, A. and Sadkowska-Tody,s M. (2012): Foodborne infections and intoxications in Poland in 2010. Przegl. Epidemiol., 66, 241-248.

Bennett, R.W. and Lancette, G.A. (2001): Staphylococcus aureus. In: FDA Bacteriological 1 Manual. $8^{\text {th }}$ Ed. Gaither sburg, MD, AOAC International: 12.

Bergdoll, M.; Chu, P.S.; Borja, C.R.; Huang, I-Y. and Weiss, K.F. (1967): The staphylococcal enterotoxins. Jpn. J. Microbiol. (11): 358-368.

Berrang, M.E.; Cox, N.A.; Frank, J.F. and Buhr, R.J. (1999): Bacterial penetration of the egg 
shell and shell membranes of the chicken hatching egg: A review. J. Appl. Poult. Res.;(8): 499-504.

Board, R.G. and Tranter, H.S. (1995): The microbiology of eggs. In: W. J. Stadelman and Coterill O.J. (eds). Egg Science and technology. $4^{\text {th }}$ ed. Haworth Press Inc. New York.

Casey, A.L.; Lambert, P.A. and Elliott, T.S.J. (2007): Staphylococci. Int. J. Antimicrob. Ag. (29): S23-S32.

CDC (Centers for Disease Control and Prevention) (2013): Antibiotic Resistance Threats in the United States, 2013 Available at: http://www.cdc.gov/drugresistance/threatreclones oh healthcare-, community- and livestock-associated methicillin-resistant Staphylococcus aureus: blurring of thetraditional definitions. J. Global. Antimicrob. Res. 6,95 -101.

CLSI/NCCLS (Clinical \& Laboratory Standards Institutel National Committee for Clinical Laboratory Standards) (2001): Development of in vitro susceptibility testing criteria and quality control parameters; approved guideline, $2^{\text {nd }}$ edn. CLSI/NCCLS Document M23-A2, CLSI/NCCLS, Wayne, PA.

Corrente, M.; Normanno, G.; Martella, $V$. , Bellacicco, A.L. and Quaglia, N.C. (2007): Comparison of methods for the detection of methicillin resistance in Staphylococcus aureus isolates from food products. Lett Appl Microbiol.; 45: 535-9.

Cuny, C.; Wieler, L.H. and Witte, W. (2015): Livestock- associated MRSA: the impact on humans. Antibiotics 4, 521-543.

De Reu, K.; Grijspeerdt, K.; Heyndrickx, M.; Zoons, J.; De Baere, K.; Uyttendaele, M. and Herman, L. (2005): Bacterial eggshell contamination in conventional cages, furnished cages and aviary housing systems for laying hens. Br. Poult. Sci.; (46): 149-155.

Deurenberg, R.H.; Vink, C.; Kalenic, S.; Friedrich, A.W.; Bruggeman, C.A. and Stobberingh, E.E. (2007): The molecular evolution of methicillin-resistant Staphylococcus aureus. Clin. Microbiol. Infect.13, 222-235.

EFSA (2014): European Food Safety Authority, BIOHAZ Panel (EFSA Panel on Biological Hazards). Scientific Opinion on the public health risks of table eggs due to deterioration and development of pathogens. EFSA Journal. 12 (7), 3782-3929.

Eman, F.A.L. and Saad, M.F. (2015): Microbiological profile of leaking chicken table eggs. I.J.S.N., 6 (1): 51-55.

ENC (Egg Nutrition Center) (2004): Egg protein fact sheet. Emerging Infectious Disease. 4:667-668.
Evêncio-Luz, L.; Lima-Filho, J.V. and Evêncio-Neto, $J$. (2012): Occurrence of Salmonella sp. and coagulase-positive staphylococci in raw eggs and Coalho cheese: comparative study between two cities of Brazil's northeast. Braz J Microbiol. 2012 Oct-Dec; 43(4): 1463-1466. doi: 10.1590/S1517838220120004000030 .

Froning G.W. (1998): Recent advances in egg products research and development. University of Nebraska-Lincoln.

Garcia-Alvarez, L.; Holden, M.T.; Lindsay, H.; Webb, C.R. and Brown, D.F. (2011): Meticillin-resistant Staphylococcus aureus with a novel mecA homologue in human and bovine populations in the UK and Denmark: descriptive study. Lancet Infect Dis.; 11: 595-603.

Ghasemian, S. (2011): The prevalence of bacterial contamination of table eggs from retails markets by Salmonella spp., Listeria monocytogenes, Campylobacter jejuni and Escherichia coli in Shahrekord, Iran. Jundishapur Journal of Microbiology. 4(4): 249-253.

Goja, A.M.; Ahmed, T.A.A.; Saeed, S.A.M. and Dirar, H.A. (2013): Isolation and Identification of Staphylococcus spp. in Fresh Bee. Pakistan Journal of Nutrition 12 (2), 114-120.

Haeghebaert, S.; Le Querrec, F.; Gallay, A.; Bouvet, P.; Gomez, M. and Vaillant, V. (2002): Les toxi-infections alimentaires collectives en France, en 1999 et 2000. Bull. Epidemiol. Hebd '. (23): 105-109.

Harris, L.G.; Foster, S.J. and Richards, R.G. (2002): An introduction to Staphylococcusaureus, and techniques for identifying and quantifying $S$. aureus adhesins in relation to adhesion to biomaterials. Eur Cell Mater;(4): 39-60.

Howard, Z.R.; O’Bryan, C.A.; Crandall, P.G. and Ricke, S.C. (2011): Salmonella enteritidis in shell eggs: Current issues and prospects for control. Food Research International. 45: 755-764.

ISO (2003b): ISO standard DIS 6888:2003(E): Horizontal method for the enumeration of Coagulase Positive Staphylococci (Staphylococcus aureus and other species).

Jerzy, R. and Dagmara, S.P. (2009): Antimicrobial defense mechanisms of chicken eggs and possibilities for their use in protecting human and animal health. Division of avian diseases, Institute of biological bases of animal diseases University of life sciences in Lublin.

Kadariya, J.; Smith, T.C. and Thapaliya, D. (2014): Staphylococcus aureus and staphylococcal food-borne disease: An ongoing challenge 
inpublic health. Bio. Med. Res. Int.;(2014): $1-9$.

Kamau, N.P.M.; Dolci, S.; Jans, C.; Wangoh, J. and Lacroix, C. (2013): Phenotypic and genotypic antibiotic resistance patterns of Staphylococcus aureus from raw and spontaneously fermented camel milk. Eur J Nutr Food Safety. 2013; 3: 87-98.

Kasozi, K.I.; Tingiira, J.B. and Vudriko, P. (2014): High prevalence of subclinical mastitis and multidrug resistant Staphylococcus aureus are a threat to dairy cattle production in Kiboga District (Uganda). Open J Vet Med.; 4: $35-43$.

Koneman, E.W. (1997): Color Atlas and Textbook of Diagnostic Microbiology. 5th ed. Philadelphia: Lippincott, J.B.

Le Loir, Y.; Baron, F. and Gautier, M. (2003): Staphylococcus aureus and food poisoning. Genet. Mol. Res.; (2): 63-76.

MacFaddin, J.F. (2000): Coagulase test. In: Biochemical test for identification of medical bacteria, Williams \& Wilkins, Philadelphia, pp. 105-119.

McClure, J-A.; Conly, J.M.; Lau, V.; Elsayed, S.; Louie, T.; Hutchins, $W$. and Zhang, K. (2006): Novel multiplex PCR assay for detection of the staphylococcal virulence marker Panton-Valentine leukocidin genes and simultaneous discrimination of methicillin-susceptible from -resistant staphylococci. J. Clin. Microbiol., 44: 1141114.

McCormick, J.K.; Yarwood, J.M. and Schlievert, P.M. (2001): Toxic shock syndrome and bacterial superantigens: An update. Annu. Rev. Microbiol.; (55): 77-104.

Messens, W.; Grijspeerdt, $K$. and Herman, $L$. (2006): Eggshell penetration of hen's eggs by Salmonella enteric serovar enteritidis upon various storage conditions. British Poultry Science. 47: 554-560.

Moats, M.A. (1980): Classification of bacteria from commercial egg washers and washed and unwashed eggs. J. Applied and Environmental Microbiology, 40: 710-714.

Normanno, G.; Corrente, M.; La Salandra, G.; Dambrosio, A. and Quaglia, N.C. (2007): Methicillin-resistant Staphylococcus aureus (MRSA) in foods of animal origin product in Italy. Int. J. Food Microbiol.;117: 219-22.

Otalu, O.J.; Kabir, J.; Okolocha, E.C. and Umoh VJ. (2011): Multi-drug Resistant Coagulase Positive Staphylococcus aureus from Live and Slaughtered Chickens in Zaria, Nigeria. International Journal of Poultry Science 10 (11): 871-875.

Piyali, D. and Pranab, B.M. (2016): Prevalence of Staphylococcus in raw meat samples in Southern Assam, India, Journal of
Agriculture and Veterinary Science 9, 2329.

Pyzik, E. and Marek, A. (2012): Characterization of bacteria of the genus Staphylococcus isolated from the eggs of Japanese quail (Coturnix coturnix japonica). Polish J. Vet. Sci., 15, 767-772.

Pyzik, E.; Marek, A. and Hauschild, T. (2014): Characterisation of Staphylococcus aureus and Staphylococcus aureus-like strains isolated from table eggs. Bull. Vet. Inst. Pulawy.; 58: 57-63.

Rahimi, E.; Nonahal, F. and Salehi, E.A. (2013): Detection of classical enterotoxins of Staphylococcus aureus strains isolated from raw meat in Esfahan, Iran. Health Scope.; (2): 95-98.

Ricke, S.C.; Birkhold, S.G. and Gast, R.K. (2001): Eggs and egg products. In compendium of methods for the microbiological examination of foods, 4th ed. Downes F. P. and Ito K. eds. American Public Health Association, Washington, D.C. 473-479.

Rossolini, G.M.; Arena, F.; Pecile, P. and Pollini, S. (2014): Update on the antibiotic resistance crisis. Curr. Opin. Pharmacol.18,56-60.

Saif, Y.M.; Calnek, B.W.; Barnes, H.J.; Beard, C.W. and McDougald, L.R. (2009): Diseases of Poultry.10th edition, Iowa State University Press, Iowa, USA.

Samah, E.; Soad, A.N. and Ahmed, M.E. (2015): Multidrug resistant bacterial pathogens in eggs collected from backyard chickens. Assiut Vet. Med. J., 61 (144): 1-17.

Sergelidis, D. and Angelidis, A.S. (2017): Methicillin-resistant Staphylococcusaureus: a controversial food-borne pathogen. Letters in Appl. Microbiol.,64, 409-418.

Shimaa, E-N.; Mohamed, W.A.E.A.; Soad, A.N. and Serageldeen, S. (2017): Prevalence of Toxigenic and Methicillin Resistant Staphylococci in Poultry Chain Production J. of Advanced Vet. Res.,7 (2): 33-38.

Skov, R.L. and Jensen, K.S. (2009): Communityassociated methicillin-resistant Staphylococcus aureus as a cause of hospital-acquired infections. J. Hosp. Infect. 73, 364-370

Speck, M.L. (1976): Compendium of Methods for Microbiological Examination of Food. ed., American Public Health Association, Washington, D.C.

Stapleton, P.D. and Taylor, P.R. (2002): Methicillin resistance in Staphylococcus aureus: Mechanisms and modulation. Sci. Progr.; (85): 57-72.

Stęień-Pyśniak, D.; Marek, A. and Rzedzicki, J. (2009): Occurrence of bacteria of the genus Staphylococcus in table eggs descended from different sources. Pol. J. Vet. Sci. 12: 481-484. 
Suleiman, A.; Zaria, L.T.; Grema, H.A. and Ahmadu, P. (2013): Antimicrobial resistant coagulase positive Staphylococcus aureus from chickens in Maiduguri, Nigeria. Sokoto Journal of Veterinary Sciences (2013). 11(1): 51-55.

Syed, M.A.; Shah, S.H.H.; Yasmin, S.; Shafi-urRehman, S.; Khan, M.A.; Barrett, J.B.; Tiffanie, A.W.; Bushra, J.; Abbasi, S.A. and Charlene, R.J. (2018): Detection and Molecular Characterization of MethicillinResistant Staphylococcus aureus from Table Eggs in Haripur, Pakistan. Foodborne Pathog Dis., 15(2): 86-93.

Taj, Y.; Farhan, E.A. and Kazmi, S.U. (2010): Current pattern of antibiotic resistance in Staphylococcus aureus clinical isolates and the emergence of vancomycin resistance. J. Coll. Phys. Surg. Pak.; (20): 728-732.

Tamarapu, S.; McKillip, J.L. and Drake, M. (2001): Development of a multiplex polymerase chain reaction assay for detection and differentiation of Staphylococcus aureus in dairy products. J. Food Prot.;(64): 664-668.

Van Rijen, M.M.L.; Van Keulen, P.H. and Kluytmans, J.A. (2008): Increase in a Dutch hospital of methicillin-resistant Staphylococcus aureus related to animal farming. Clin. Infect. Dis. 46, 261-263.

Vincze, S.; Stamm, I.; Kopp, P.A.; Hermes, J.; Adlhoch, C.; Semmler, T.; Wieler, L.H. and Lubke-Becker, A. (2014): Alarming proportions of methicillin-resistant Staphylococcus aureus (MRSA) in wound samples from companion animals, Germany 2010-2012.PLoS ONE9,e85656.

Wendlandt, S.; Schwarz, S. and Silley, P. (2013): Methicillin-resistant Staphylococcus aureus: a food-borne pathogen? Annu. Rev. Food Sci. Technol.4, 117-139.

Wooldridge, M. (2012): Evidence for the circulation of antimicrobial resistant strains and genes in nature and especially between humans and animals, Rev. sci. tech. Off. int. Epiz., 2012, 31 (1), 231-247.

Yurdakul, N.E.; Erginkaya, Z. and Ünal, E. (2013): Antibiotic Resistance of Enterococci, Coagulase Negative Staphylococci and Staphylococcus aureus Isolated from Chicken Meat. Czech J. Food Sci. 31, 14-19.

\title{
عزل وتوصيف الميكروب المكور العنقودي الأهبي المقاوم للميثيسلين من بيض المائدة \\ مروة محمد نبيل الجندي ، منال محمد امبين \\ E-mail: ahmednofel125@yahoo.com Assiut University web-site: www.aun.edu.eg
}

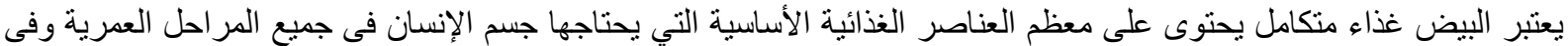

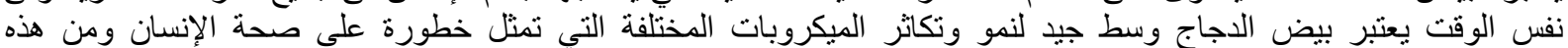

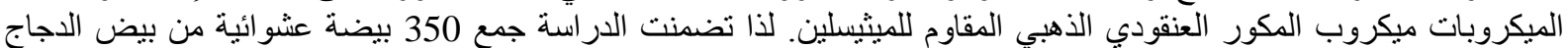

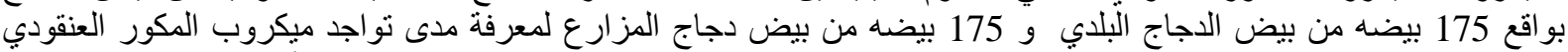

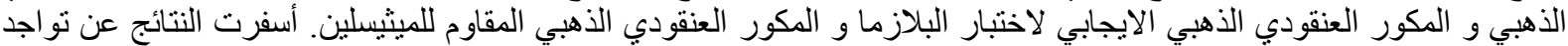

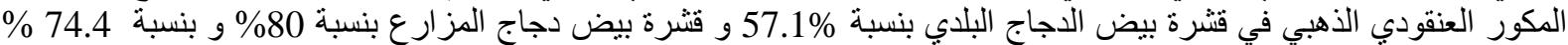

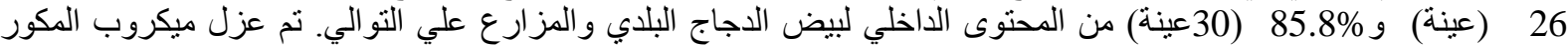

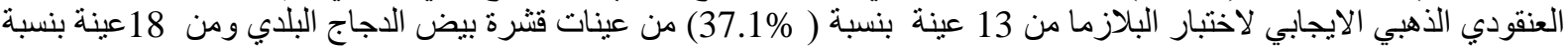

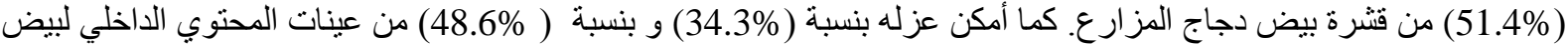
الدجاج البلدى ودجاج المزارع على التوالي. التعرف عاف على جين (mecA) للمكور العنقودي الذهبي المقاوم للمينيسلين عن طريق

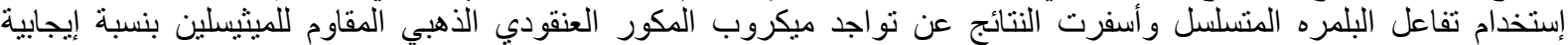

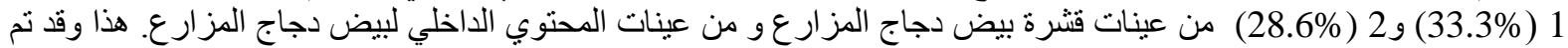

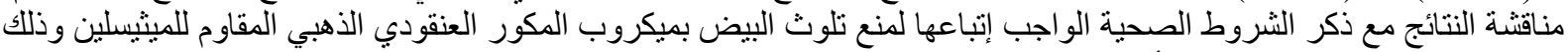

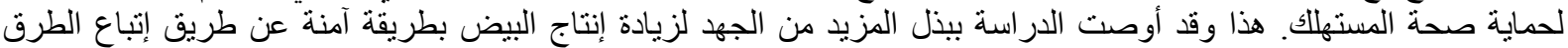

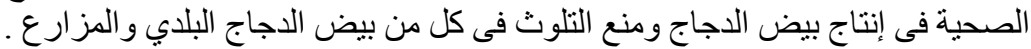

